\title{
Bibliography of Personal Names, 1960
}

\section{ELSDON C. SMITH}

$\mathrm{I}_{\mathrm{r}}$ missed, and also to items in 1961 for the next annual installment of this bibliography.

\section{Acronyms Dictionary}

Detroit (Michigan), 1960. pp. 211.

Bauer, Harry C., Confused Authorships

in Library Review, No. 136, Winter, 1960, pp. 560-565. Glasgow, 1960.

On authors with the same name.

Bodkin, E. H., Names and Arms Clauses

in The Solicitor, Vol. 27, July, 1960, pp. 196-197. London, 1960.

A discussion of the validity of names and arms clauses in England.

Chamberlin, Jo Hubbard, "I'm Tender About Gender"

in Coronet, Vol. 47, February, 1960, pp. 55-57. Chicago, 1960.

On given names used by both sexes. Interesting.

deYoung, John E., Editor, The Use of Names by Micronesians

Second Edition, Guam (M.I.), 1960. (First Edition, 1958). pp. 124.

A collection of articles on Yapese, Paluauan, Pompean, Trukese, Marshallese and Mariana personal names by various writers. Cf. below, p. $181 \mathrm{f}$.

Droege, G[eart] B., Frisian Given Names in French Flanders

in Fryske Studzjes oan bean oan Prof. Dr. J. H. Brouwer op syn sechstichste jierdei 23 a, pp. 413-418. Assen, 1960.

Eder, Phanor J., The Right to Choose a Name

in The American Journal of Comparative Law, Vol. 8, Autumn, 1959, pp. 502-507. Ann Arbor (Mich.), 1959.

On legal restrictions on the choice of forenames in Argentina and elsewhere.

Fleming, Eugene, D., The Name Game

in The American Weekly, October 9, 1960, pp. 12-14. New York, 1960. - General on personal names.

Gelb, I[gnace] J[ay], The Names of the Goddess Innin

in Journal of Near Eastern Studies, Vol. 19, April, 1960, pp. 72-79.

Chicago, 1960.

On the name of this Sumerian-Akkadian goddess. 
Georgacas, Demetrius J., Sixth International Congress of Onomastic Sciences

in Names, Vol. 8, June, 1960, pp. 102-108. Youngstown, 1960.

A comprehensive report.

Gibson, John E., What Your Name Reveals

in Today's Health, Vol. 38, May, 1960, pp. 16-17. (Abstracted with title, Your Signature Shows You Up, in Science Digest, Vol. 48, September, 1960, pp. 88-90. New York, 1960.)

Chicago, 1960.

On your feelings towards your name and how you sign it.

Gottlieb, Nathan, [Choosing and Giving Names]

in his A Jewish Child is Born. New York, 1960.

Haeringen, C[oenraad] B[ernardus], Onomastics

in his Netherlandic Language Research, Chapter 11, pp. 83-86.

Leiden, 1954, Second Edition, Leiden, 1960.

About works on names.

Hall, Ron, The Sociologue or the Initial Advantage

in Crossbow, Vol. 3, Summer, 1960, pp. 46-49. London, 1960.

Propounds Hall's Law: "For any sufficiently large group of people the average number of initials (including Christian and surnames) possessed by members of that group is a direct measure of the predominant social class of the group."

Harris, Margaret C., What's In a Name?

in Daughters of the American Revolution Magazine, Vol. 94, June-July, 1960, p. 446. Washington, 1960.

Just a short list of odd names from the D.A.R. Magazine.

Holman, Winifred Lovering and Jacobus, Donald Lines, Female Diminutives

in The American Genealogist, Vol. 34, April, 1958, pp. 96-98. New Haven (Conn.), 1958.

On nicknames and interchangeable forms in New England, 1700 to 1880 .

Hunt, John G., and Jacobus, Donald L[ines], Brothers and Sisters of the Same Given Names

in The American Genealogist, Vol. 36, July, 1960, pp. 158-159. New Haven (Conn.), 1960.

Gives several examples.

Krahn, Cornelius, Mennonite Names of Persons and Places

in Mennonite Life, Vol. 15, January, 1960, pp. 36-38. North Newton (Kans.), 1960.

On Mennonite personal names in America. 
Kramer, F. L., Names Not Brief

in Names, Vol. 8, June, 1960, pp. 87-88.

Youngstown (Ohio), 1960.

About the long name of one member of the American Name Society.

Lambert, Eloise, and Pei, Mario, Our Names, Where They Came From and What They Mean. New York, 1960, pp. 192.

General on personal names. Juvenile.

Lambert, Tom, A Little Boy Named Differential

in Catholic Digest, Vol. 24, April, 1960, pp. 94-96. St. Paul (Minn.), 1960.

On first names given in Russia. Condensed from the New York Herald Tribune.

Lowe, Robert W., French Name Words in the Classroom

in The Modern Language Journal, Vol. 44, February, 1960, pp. 71

to 74. Menasha (Wis.), 1960.

On proper names used as symbols or in idiomatic expressions.

Mook, Maurice A., Nicknames Among the Amish

in Keystone Folklore Quarterly, Vol. 5, Winter, 1960, pp. 3-12. University Park (Pa.), 1960.

Moore, Richard B., The Name "Negro"; Its Origin and Evil Use.

New York, 1960. pp. 82.

Wants to substitute "Afroamerican" or "African" for "Negro."

Moser, Gerald M., Portuguese Family Names

in Names, Vol. 8, March, 1960, pp. 30-52.

Youngstown (Ohio), 1960.

On Portuguese surnames in the United States.

Names and Where They Came From

in Compton's Pictured Encyclopedia, Vol. 10, pp. 3-5. Chicago, 1960.

General on personal names.

Naming All the Names

in Newsweek, Vol. 56, July 18, 1960, p. 50. Dayton (Ohio), 1960.

On place and personal names.

Opie, Peter and Iona, Nicknames and Epithets

in their The Lore and Language of Schoolchildren, Chapter 9, pp. 154-174. Oxford, 1959.

On the use of names in the speech of children.

Padrnos, Dennis, Fictitious Names Statute

in South Dakota Law Review, Vol. 5, Spring, 1960, pp. 133-139.

Vermillion (S.D.), 1960.

A discussion of the law. 
Pauls, John P., Surnames of Soviet Russian and other Communist Celebrities

in Names, Vol. 8, December, 1960, pp. 220-239. Youngstown (Ohio), 1960.

Poos, John Peter, What's in Your Name?

in This Day, Vol. 11, May, 1960, p. 13. St. Louis, 1960.

General on personal names.

Power, William, Middleton's Way With Names

in Notes and Queries, Vol. 205 (New Series Vol. 7), January, 1960, pp. 26-29; February, 1960, pp. 56-60; March, 1960, pp. 95-98; April, 1960, pp. 136-140; May, 1960, pp. 175-179. London, 1960.

On names in Middleton.

Price, Roger, The Roger Price Theory of Nomenclature in Playboy, Vol. 7, March, 1960, pp. 39-40, 80. Chicago, 1960.

A humorous article giving fanciful characteristics to persons with certain given names.

Price, Roger, and Stern, Leonard, What Not to Name the Baby New York, 1960. pp. 127.

Fanciful characteristics of persons with certain given names, listed in alphabetical order.

Pulgram, Ernst, New Evidence on Indo-European Names in Language, Journal of the Linguistic Society of America, Vol. 36, April-June, 1960, pp. 198-202. Baltimore, 1960.

Rider, Priscilla L., Legal Protection of the Manifestations of Individual Personality - The Identity-Indicia

in Southern California Law Review, Vol. 33, Fall, 1959, pp. 31-70. Los Angeles, 1960.

Schmidt, J[acob] [Edward], Baby Name Finder Springfield (Ill.), 1960. pp. xix, 390.

A dictionary of Christian names with numerous baby pictures; also the names in alphabetical order by meanings.

Scott, Jr., Clayton S., Corporate Nicknames in the Stock Market in American Speech, Vol. 35, October, 1960, pp. 193-202. New York, 1960.

On nicknames and ticker symbols of corporations in America.

Sharify, Nasser, Iranian Personal Names: Their Characteristics and Usage in Unesco Bulletin for Libraries, Vol. 14, September-October, 1960, pp. 205-209, 232. Paris (France), 1960.

Article drawn from Sharify's Cataloging of Persian Works. 
VIth International Congress of Onomastic Sciences, München: 24.-28. August 1958. Reports of Congress Band I, Chief Reports.

München, 1960. pp. [vii], 157.

Smith, Elsdon C., Bibliography of Personal names, 1959. in Names, Vol. 8, June, 1960, pp. 172-179. Youngstown (Ohio), 1960.

Smith, Elsdon C., Names, Personal

in The World Book Encyclopedia, Vol. 13, pp. 5-8. Chicago, 1960. General on personal names.

Smith, Elsdon C., What Do Their Names Mean?

in Parade, The Sünday Picture Magazine, January 17, 1960, p. 11. New York, 1960.

On the surnames of twelve prominent people.

Smith, Henry Ladd, Secrets of a Namephomaniac

in Pageant, Vol. 16, December, 1960, pp. 80-81. Chicago, 1960.

On some odd personal names.

Stewart, George R., Murder and Onomatology

in The Nation, Vol. 190, April 9, 1960, pp. 313-316. New York, 1960.

On efforts to prove that a name does not exist, in connection with the Motherwell murder trial.

Stone, Harry, Dickens and the Naming of Sam Weller

in The Dickensian, Vol. 56, Winter, 1960, pp. 47-49. London, 1960.

On names in Dickens.

Sundby, Bertil, Notes on Names

in English Studies, Vol. 40, April, 1959, pp. 109-112. Amsterdam, 1959.

On a few English place and personal names.

Van Eerde, John, Names in Provence

in College Language Association (CLA) Journal, Vol. 3, December, 1959, pp. 119-122. Baltimore, 1960.

On names of persons and peoples of Provence in France.

W., M. M., Names and Arms Clauses

in The Law Journal, Vol. 110. September 16, 1960, pp. 599-600. London, 1960.

A discussion of the validity of names and arms clauses in England.

Waggoner, Walter H., How's That Again? Take an old English Name of

Twelve Letters and Chances are Half Will be Silent.

in New York Times Magazine, September 25, 1960, p. 41. New York, 1960.

On the pronunciation of some English surnames. 
What's in a Name?

in The Economist, Vol. 194, February 13, 1960, pp. 602-603. London, 1960.

On the Queen's surname of Mountbatten-Windsor.

Withycombe, E[lizabeth] G., "N." and "M." in the Book of Common Prayer

in Notes and Queries, Vol. 205, New Series, Vol. 7, August, 1960, pp. 286-288. London, 1960.

On the meaning of "M."

Wong, Jade Snow, How to Pick a Chinese Name

in Holiday, Vol. 27, May, 1960, pp. 36, 38-39. Philadelphia, 1960. On Chinese given names.

Yeutter, Frank, Current Nicknames Lack Sparkle of Old Monikers in The Sporting News, July 27, 1960, p. 14. St. Louis, 1960.

On nicknames of baseball players.

Evanston, Illinois 